\title{
THE DIVINE IMAGE AND COMMUNION OF PERSONS: AN EXAMINATION OF GENDER ISSUES IN JOHN PAUL II
}

\author{
Hyginus Chibuike Ezebuilo \\ Nnamdi Azikiwe University, Nigeria
}

John Paul II resisted all attempts to incorporate women into the Holy Orders during his papacy, yet he is a strong advocate of gender equality. This presupposes that equality for John Paul II precludes gender differentiation. If so, then differentiated gender roles reflect inequality. However, is this conclusion right? Must all forms of equality obliterate all differences? Or, is it possible for there to be an equality of differences? This does not seem possible because the difference as such lacks commonality, whereby they can be compared and known as equal. The question becomes whether the commonality that allows for comparison must be identical, that is, must equality be a univocal concept? These are the questions that border this study as it examines gender issues in John Paul II. He univocally supports gender equality while upholding gender roles that would allow equality to be based upon a commonality that is analogous rather than univocal or equivocal. There is no room for the slightest sexist discrimination anywhere in human life. But the equality of men and women is an analogous one so that the differentiation of the sexes must not be lost, not in any of our behavior, laws, customs, and traditions. Our laws must somehow allow for the difference between the sexes, and the era demanded by the feminists would have been a tragic mistake. The research method employed is a critical method. The study discovers that the Pope expresses a commitment to gender equality based upon a sacramental theology wherein nature images the divine and wherein the equality of man and woman was definitively biblical. For him, man and woman are equally persons and equally image of God in whose likeness, both were created. Why then are these equal images sexually differentiated? This is the problem that this paper confronts.

\section{INTRODUCTION}

It is becoming increasingly clear that we are now facing what might be called $a$ gender crisis, especially in the field of affectivity and sexuality. In many educational institutions today, curricula are being planned and implemented which, according to the Congregation for Catholic Education (2019), in the document, "Male and female 
He created them: Towards a path of dialogue on the question of gender theory in education," which allegedly convey a neutral conception of the person and life, which, in fact, reflects an anthropology that is opposed to faith and right reason. The disorientation regarding anthropology, which is a widespread feature of our cultural landscape, has undoubtedly helped destabilize the family as an institution, bringing with it a tendency to cancel out the differences between men and women, presenting them instead as merely the product of historical and cultural conditioning. This current mentality is characterized by challenges emerging from varying forms of an ideology that is given the general name 'gender theory,' which for the Congregation for Catholic Education (2019), denies the differences and reciprocity in nature of a man and a woman and envisages a society without sexual differences, thereby eliminating the anthropological basis of the family. This ideology leads to legislative enactments that promote a personal identity and emotional intimacy radically separated from the biological difference between males and females. Consequently, human identity becomes the choice of the individual, one which can also change over time.

However, the Congregation for Catholic Education (2019) maintains the Christian vision of anthropology, which sees sexuality as a fundamental component of one's personhood. It is one of its modes of being, of manifesting itself, communicating with others, and of feeling, expressing, and living human love. Therefore, our sexuality plays an integral part in the development of our personality. In fact, in the view of the Congregation for the Catholic Education (2019, no 4)

It is from (their) sex that the human person receives the characteristics which, on the biological, psychological, and spiritual levels, make that person a man or a woman, and thereby largely conditions his or her progress towards maturity and insertion into society.

As each person grows, such diversity, linked to the complementarity of the two sexes, allows a thorough response to the design of God according to the vocation to which each is called. In light of this, a positive approach to gender issues must consider the totality of the person and insist, therefore, on the integration of the biological, social, and spiritual elements.

If we wish to take an approach to the question of gender theory that is based on the path of dialogue, it is vital to bear in mind the distinction between the ideology of gender on the one hand, and the whole field of research on gender that the human sciences have undertaken, on the other. The Congregation for the Catholic Education (2019, no 6) further maintains that while the ideologies of gender claim to respond, as Pope John Paul II has indicated, "to what are at times understandable aspirations," they also seek "to assert themselves as absolute and unquestionable, even dictating how children should be raised," and thus preclude dialogue. However, other work on gender has been carried out, which tries instead to achieve a deeper understanding of the ways in which sexual difference between men and women is lived out in a variety of cultures. It is in relation to this type of research that John Paul II offers his reflection on gender issues. 
The Holy Father affirms the strict equality of women with men in the dignity of being persons. Our equality, in fact, is a religious equality, the deepest equality of all. It is revealed chiefly in two places: the Adam and Eve story in the book of Genesis and the account of Jesus' many conversations with women in the Gospels. But our personal dignity is differentiated sexually, and so, equality is not sameness, and difference is not inequality. Thus, we shall begin with the general notion of universal human or personal dignity and then see how that dignity is particularized in the female sex.

For John Paul II in his book, On the Dignity and Vocation of Women (1988), the equality of men and women is clear from the creation of Eve as Adam's helpmate, a helpmate precisely in the task of being a person. That task requires another person with whom a 'unity of the two' might be formed, so that man, precisely as such a unity, might be in the image and likeness of God. He noted that Adam recognized Eve's equality with himself in the joyous cry with which he greeted her, "Bone of my bone and flesh of my flesh" (Gen.2:23). Accordingly, John Paul II (1988, 22) avers that:

Men and women thus have a common dignity and vocation, a kind of fulfillment that is possible only to persons: the communion personarum, or communion of persons, that mysterious way in which we can be truly one with each other and still find our individual identities intact and even enhanced.

This communion is the theme of almost everything that Pope John Paul II has written. It is, in fact, holiness, our communion with the Divine Communion of Father, Son, and Holy Spirit. It is the grace by which we participate in the inner life of the Trinity. The common call to men and women, then, the dignity of the vocation that we share, is the call to holiness. Furthermore, John Paul II $(1988,23)$ explains that:

Jesus recognized this equality in all his encounters with women, where his behavior was startlingly countercultural. Contrary to all the customs and traditions of his time, he spoke to women, in public, and about the most serious matters of human life: the identity of the Messiah, resurrection, the meaning of his own death. He was the first to call Jewish women 'daughters of Abraham.' He made women the primary witnesses of his death and the first to know of, and tell the men about, his Resurrection. Such dignity had never before been accorded to women.

\section{GENDER AND GENDER THEORY: CONCEPTUAL FRAMEWORK}

In common parlance, gender refers to the socially constructed characteristics of women and men - such as norms, roles, and relationships of and between groups of women and men. It varies from society to society and can be changed. While most people are born either male or female, they are taught appropriate norms and behaviors - including how they should interact with others of the same or opposite sex within households, communities, and workplaces. When individuals do not 'fit' established gender norms, they often face stigma, discriminatory practices, or social exclusion. 
According to Mary Rousseau (1990), “gender is the range of characteristics pertaining to, and differentiating between, masculinity and femininity." However, in Cornell (1949), John Money introduced the terminological distinction between biological sex and gender as a role in 1955. However, John's meaning of the word did not become widespread until the 1970s, when feminist theory embraced the concept of a distinction between biological sex and the social construct of gender. Today, the term 'sex' is being used as a biological classification and 'gender' as a person's self-representation as male or female, or how that person is responded to by social institutions based on the individual's gender representation. In other words, sex is approached as biological features while gender as a social construct. Mary Rousseau (1990) writes that although "gender and sex are separate concepts; they are interlinked in that gender discrimination often results from stereotypes based on what is expected of members of each sex." In the case, between J.E.B. v. Alabama T.B., according to Cornell (1949), the United States Supreme Court, Justice Antonin Scalia writes:

The word 'gender' has acquired the new and useful connotation of cultural or attitudinal characteristics (as opposed to physical characteristics) distinctive to the sexes. That is to say, gender is to sex as feminine is to female and masculine is to male.

This assertion ultimately offers a background to what is now known as gender theory.

However, according to the Congregation for Catholic Education (2019), the primary outlook needed for anyone who wishes to take part in dialogue is listening. It is necessary, above all, to listen carefully to and understand cultural events of recent decades. The $20^{\text {th }}$ century brought new anthropological theories and with them the beginning of gender theory. These were based on a reading of sexual differentiation that was strictly sociological, relying on a strong emphasis on the freedom of the individual. In fact, around the middle of the last century, a whole series of studies were published which accentuated time and again the role of external conditioning, including its influence on determining personality. When such studies were applied to human sexuality, they often did so with a view to demonstrating that sexual identity was more a social construct than a given natural or biological fact.

These schools of thought were united in denying the existence of any originally given element in the individual, which would precede and at the same time constitute our personal identity, forming the necessary basis of everything we do. According to such theories, the only thing that matters in personal relationships is the affection between the individuals involved, irrespective of sexual difference or procreation, which would be seen as irrelevant in the formation of families. Thus, the institutional model of the family (where a structure and finality exist independent of the subjective preferences of the spouse) is bypassed in favor of a vision of family that is purely contractual and voluntary.

Over the course of time, stemming from the document, Congregation for the Catholic Education (2019) argues that gender theory has expanded its field of application. At the beginning of the 1990s, "its focus was upon the possibility of the individual determining his or her own sexual tendencies without having to take account of the reciprocity and complementarity of male-female relationships, nor of 
the procreative end of sexuality." Furthermore, it was suggested that one could uphold the theory of a radical separation between gender and sex, with the former having priority over the latter. Such a goal was seen as an important stage in the evolution of humanity, in which "a society without sexual differences" could be envisaged.

In this cultural context, it is clear that sex and gender are no longer synonymous or interchangeable concepts since they are used to describe two different realities. Sex is seen as defining which of the two biological categories one belonged to. Gender, on the other hand, would be the way in which the differences between the sexes are lived in each culture. The problem here does not lie in the distinction between the two terms, which can be interpreted correctly, but in the separation of sex from gender. This separation is at the root of the distinctions proposed between various "sexual orientations," which are no longer defined by the sexual difference between male and female, and can then assume other forms, determined solely by the individual, who is seen as radically autonomous. Further, the concept of gender is seen as dependent upon the subjective mindset of each person, who can choose a gender not corresponding to his or her biological sex, and therefore with the way others see the person - a development which the Congregation for Catholic Education (2019) referred to as transgenderism.

In a growing contraposition between nature and culture, the propositions of gender theory converge in the concept of 'queer,' which refers to "dimensions of sexuality that are extremely fluid, flexible, and as it were, nomadic." This culminates in the assertion of the complete emancipation of the individual from any a priori given sexual definition and the disappearance of classifications seen as overly rigid. This would, in turn, create a new range of nuances that vary in degree and intensity according to both sexual orientation and the gender one has identified oneself with.

This phenomenon has, indeed, led to calls for public recognition of the right to choose one's gender, and of a plurality of new types of unions, in direct contradiction to the model of marriage as being between one man and one woman, which is portrayed as a vestige of patriarchal societies. The ideal presented is that the individual should be able to choose his or her own status and that society should limit itself to guaranteeing this right and even providing material support since the minorities involved would otherwise suffer negative social discrimination. The claim to such rights has become a regular part of political debate and has been included in certain pieces of national legislation.

From John Paul II's writings on gender issues, there have, however, emerged some positions that could provide points of agreement with the gender theorists - with a potential to yield growth in mutual understanding. For instance, The Pope's thoughts on this area often share a laudable desire to combat all expressions of unjust discrimination, a requirement that can be shared by all sides. There have really been delays and failings in this regard. Indeed, it cannot be denied that through the centuries, forms of unjust discrimination have been a sad fact of history and have also had an influence within the Church. This, according to John Paul II (1988), has brought a certain rigid status quo, delaying the necessary and progressive inculturation of the truth of Jesus' proclamation of the equal dignity of men and women, and has provoked accusations of a sort of masculine mentality, veiled to a greater or lesser degree by religious motives. 
Nonetheless, real-life situations present gender theory with some valid points of criticism. Gender theory (especially in its most radical form) speaks of a gradual process of denaturalization. This is a move away from nature and towards an absolute option for the decision of the feelings of the human subject. There is a need to recognize that man has a nature that he must respect and that he cannot manipulate at will. This, according to the Congregation for Catholic Education (2019), is the fulcrum on which to support a human ecology that moves from the "respect for our dignity as human beings" and from a necessary relationship of our life to "moral law, which is inscribed into our nature."

Christian anthropology has its roots in the narrative of human origins that appears in the Book of Genesis, where we read that "God created man in his own image [...] male and female he created them" (Gen.1:27). These words capture not only the essence of the story of creation but also that of the life-giving relationship between man and woman, which brings them into intimate union with God. The self is completed by the one who is other than the self, according to the specific identity of each person, and both have a point of encounter forming a dynamic of reciprocity which is derived from and sustained by the Creator.

Additionally, there is a need to reaffirm the metaphysical roots of sexual difference as an anthropological refutation of attempts to negate the male-female duality of human nature. The denial of this reality not only erases the vision of human beings as the fruit of an act of creation but creates the idea of the human person as a sort of abstraction who chooses for himself what his nature is to be.

\section{HUMAN RIGHTS AND DISCRIMINATION}

John Paul II is keenly aware of the discrimination women have faced throughout history. It is mostly anchored in the violation of universal human rights. The fact remains that greater efforts are needed to eliminate discrimination against women, especially in areas that include education, health care, politics, and employment. John Paul II $(1995 b, 6)$ also noted another form of discrimination, namely the fact that women are virtually ignored by those who write history: "History is written almost exclusively as the narrative of men's achievements, when in fact its better parts are most often molded by women's determined and persevering action for good." In particular, John Paul II (1995b, 3) posits that:

Women's dignity has often been unacknowledged and their prerogatives misrepresented; they have often been relegated to the margins of society and even reduced to servitude. This has prevented women from truly being themselves, and it has resulted in a spiritual impoverishment of humanity.

In an attempt to restore dignity to women, John Paul II turns first of all to women themselves, though he tries hard to achieve a change in consciousness in men as well. John Paul II (1995b, 8) writes:

I appeal to all men in the Church to undergo, where necessary, a change of heart and to implement, as a demand of their faith, a positive 
vision of women. I ask them to become more and more aware of the disadvantages to which women, and especially girls, have been exposed and to see where the attitude of men, their lack of sensitivity, or lack of responsibility may be at the root.

Due to the irreplaceable dignity of men and women, the Roman Pontiff urges an end to all discrimination and marginalization of women. Above all, he criticizes the degradation of women to a mere objects, which offends and violates their basic right to personhood.

Nevertheless, his proposal to assure the rehabilitation of woman's dignity involves more than simply the condemnation of discrimination and injustices, necessary though this may be. He avers that such respect must first and foremost be won through an effective and intelligent campaign for the promotion of women, concentrating on all areas of women's life and beginning with a universal recognition of the dignity of women. He points that our ability to recognize this dignity, in spite of historical conditioning, comes from the use of reason itself, which is able to understand the law of God written in the heart of every human being.

The Pope also insists that it is imperative that women themselves recognize and preserve their dignity through a corresponding lifestyle. In other to achieve this end, the ideal of the Blessed Virgin, the culminating point, the archetype, of the personal dignity of women, is indispensable. For, as John Paul II noted, in her is perfectly realized what every human person, that is, man and woman alike, should aspire to become.

\section{EQUALITY AND DIFFERENCE}

Departing from the status quo over the centuries, John Paul II teaches in no uncertain term that women and men are equal as persons before God. He believes that "both man and woman are human beings to an equal degree." According to the International Marian Research Institute (2000), both men, women are created in the image and likeness of God. Consequently, they are capable of loving and are equipped with reason, free will, and conscience. He also observes that men and women belong to the Mystical Body of Christ in the order of redemption, and are heirs of eternal life, and are called to discipleship. The power of this at first glance, rather theoretical affirmation of spiritual and metaphysical equality, is nuanced in practice by the Pope's commitment to gender difference. His work consistently draws upon the traditional view that men and women embody human nature in two contrasting but complementary ways, which means that they play distinct social roles.

Coexisting feminine and masculine subjectivity, therefore, must not imply any threat or isolation. Advocating the equality and dignity of women does not mean to play them off against men, as is often done in certain feministic circles. Quite the opposite, ideally apparent tensions should be used in a creative way through reciprocal complementarity and enrichment. John Paul II calls this the "unity of the two." Man and woman have been created as two persons in order to reach the full potential of what it means to be human. John Paul II (1995b, 10) observes: 
It also means that men and women, created as a "unity of the two" in their common humanity, are called to live in a communion of love, and in this way to mirror in the world the communion of love that is in God, through which the Three persons love each other in the intimate mystery of the one divine life.

Indeed, communion and complementarity of man and woman are anchored in the anthropological truth that both are created as an image of the Trinity. According to John Paul II $(1995 b, 11)$, he opined that within the communion of the Triune God is found absolute unity and simultaneous free unfolding of the differences of the persons and their attributes. Notwithstanding their differences, they are one; in as far as each one pursues their mission, they can communicate union. He then concludes that the communion within the Trinity is reflected in the union of man and woman: absolute unity through freedom and distinctive differences. Moreover, this can only be accomplished through love. According to the Pope, therefore, any rivalry between woman and man was not part of the divine plan, but part of human sinfulness. John Paul II (1995a, no. 4) writes:

Sadly, a long history of sin has disturbed and continues to disturb God's original plan for the couple, for the male and female, thus standing in the way of its complete fulfillment. We need to return to this plan, to proclaim it forcefully, so that women in particular - who have suffered more from its failure to be fulfilled - can finally give full expression to their womanhood and their dignity.

Such, then, is the equality of men and women in the dignity of our common vocation, the holiness by which we enter into the very life of God. However, how is this general human dignity differentiated in the two sexes so that women enjoy a distinctly feminine dignity? Here we must look to the Holy Father's phenomenology of that action in which sexual differences are dramatically clear and undeniable - the act of sexual intercourse. When that act is what it is meant to be, it is 'a great sacrament' in reference to Christ and the Church. It is then rightly called the act of making love.

In the works of Pope John Paul II, we see an emphasis on sex that is quite new and even more startling (until we understand it). According to Karol Wojtyla (1981, 270) the view of the act of making love is almost the keystone of his entire sexual ethics, his family ethics, his views on women, and his understanding of the Eucharist and the sacramental priesthood. He sees in the simultaneous orgasm of loving spouses a uniquely intense moment of the communion of persons. And in that action, he sees not only the epitome of married love but a kind of model of what all of human life should be - ecstatic and passionate reciprocal self-abandon.

As Rousseau $(1990,12)$ rightly observed, orgasm is a high point of reciprocal self-giving love. But the self-giving is different for the two spouses, different in ways that are not trivial and that cannot be overlooked. The chief difference is in the male initiative and female receptivity. For the sex act even to seem to happen, a husband must act in an energetic and obvious way, and his wife must receive his action. He exercises a kind of initiative, and she is receptive to it. However, his initiative is not 
aggressive and oppressive. It is a headlong rush to hand himself over to his woman, lock, stock, and barrel. And her receptivity is not passive and degrading. She gratefully accepts his compliment and responds with an equally active gift in kind, rushing to hand herself over to him, lock, stock, and barrel.

\section{THE HUMAN NATURE IS ANALOGOUS IN MEN AND WOMEN}

So far, we have arrived at the conclusion that for Pope John Paul II, men and women are equal persons before God. Nevertheless, equality, for him, does not mean sameness, and difference does not mean inequality. This equality is, indeed, basically analogous. To make this point clear, let us first have a quick look at the very nature of analogy. With respect to logical predication, which explained that terms are divided into three types, namely univocal, equivocal, and analogous terms. According to them, a term is univocal when it is predicated of diverse things according to exactly the same concept. For example, the term 'animal' as applied to a goat and a cow signifies the same thing: animated, sensitive, substance. In univocal prediction, according to H.J. Koren $(1960,3)$, not only that the term remains the same, but the very concept of which this term is a symbol remains exactly the same.

On the other hand, a term is said to be equivocal when it is predicated of diverse thing according to an entirely different concept. A clear example is the term 'coach' as applied to an instructor of athletics and to a certain type of vehicle or the term 'bank' as applied to financial institutions and river. Now, in equivocal prediction, the term itself remains the same, but the concept of which the term is a symbol is entirely different. Let it be noted here that it is purely accidental that two or more entirely different concepts are indicated by one and the same symbol. For this reason, Koren $(1960,4)$ maintained that such terms are said to be equivocal simply by chance or by accident. Albeit this fact, it is possible that two different things are assigned the same symbol after a thorough and conscious examination of their various attributes by the people assigning the symbol.

Furthermore, it should be noted that there is no question of equivocal concepts. For a concept by its very nature has only one thought content. For this reason, an equivocal concept would be a contradiction in terms. Yet, the same symbol may be chosen to express entirely different concepts. We may say then that equivocity occurs only externally inasmuch as in the choice of their external symbol attention is not necessarily paid to any common characteristics.

When we want to determine whether a term is univocal or equivocal, we must take into consideration the subject of which the term is predicated. If, for instance, the term 'pen' is taken only insofar as it is predictable of a certain instrument for writing, it is univocal; but if it is taken as predicable of such an instrument and of an enclosure for an animal, it is equivocal.

Finally, a term is said to be analogous if one and the same name is predicated of many according to concepts that are not entirely different but agree on some common point. In analogous predication, the term remains the same, but the concept of which the term is a symbol neither remains exactly the same, as is the case in univocal predication, nor becomes entirely different, as happens in equivocal predication, but varies yet retaining something. That is, while changing, it retains something. Thus, the 
unity of such a concept is not absolute but only relative. For instance, when my eyes perceive a sense object, I can say, 'I see,' and when my intellect understands a problem, I can still say, 'I see.'

But clearly, the act of sense-perception is absolutely different from that of intellectual perception; nevertheless, there is a certain relative unity because as the eye is related to sense-perception, so the intellect is related to intellectual perception. Consequently, one and the same term may be used to express both actions. But when I predicate this term of the eye and of the intellect, the concept signified by the term 'to see' has to be adjusted accordingly as required by the subject (the eye or the intellect). It is in this way that one concept can be predicated of things that are absolutely different insofar as they are relatively the same. For this reason, Koren (1960) avers that analogous terms are said to be equivocal by design or intentionally because man chooses the same term for the avowed purpose of expressing the relative unity which he discovers in absolutely different things.

It follows, therefore, that there are genuine differences between the sexes that are natural, not just cultural, and sexual, not just individual differences that might be found in people of either sex. They are differences in perceiving, judging, and choosing; differences in the exercise of self-giving love; differences for forming communions of persons. Thus, the Holy Father provides a crucial element for understanding women that has been missing from the public discussion, an understanding of human sexuality that neither denies nor overemphasizes the differentiation of human beings into two kinds, masculine and feminine.

By taking human nature to be analogous in men and women, he shows our absolute equality with each other as persons. And yet, he gives full value to the difference, so that sex, an obvious bodily difference, is not split off from personhood but is pervasive of it. Thus, equality does not mean sameness, and difference does not mean inequality. He avoids the dilemma of both treating men and women exactly alike or else making one sex inferior to the other. Thanks to this analogy, he offers a rich and attractive view of women's dignity that takes advantage of our special traits as women and yet sets us side by side with men in a joint, complementary search for human fulfillment that is as differentiated as people are.

So the commonality that allows for comparison must not always be identical, and as such, equality does not necessarily have to be a univocal concept. For example, equality of car drivers is univocal since the role of driving is the same for each driver. This is unlike the equality of being an artist, which is only analogical since not all artists function in the same way: some make music and other paintings. Yet all are equally great artists based on the commonality of excellence. Yet their equality is not based upon the same excellence but upon an analogous excellence arising from the relationship of the artists to art. Since those relationships pertain to excellence, they are equals; but since their excellences are different, their equality is analogical.

Similarly, John Paul II is univocally supportive of gender equality while upholding gender roles that would allow equality to be based upon a commonality that is analogous rather than univocal or equivocal. As we shall see below, he would also have to hold that ordained priesthood is a gender role. A gender role is a set of societal norms dictating the types of behaviors that are generally considered acceptable, appropriate, or desirable for people based on their actual (or perceived) sex or sexuality. 


\section{ONTOLOGICAL AND SACRAMENTAL JUSTIFICATIONS FOR NON- WOMEN PRIESTLY ORDINATION}

This ongoing brings us, of course, to the flashpoint of feminist anger against the Pope - his insistence that the ordained priesthood be open only to men. It is no accident that women's ordination is such a flashpoint because it is the focus of clashing views on human sexuality. For those who insist on absolutely everything being open to women, sexuality has no personal importance. It is relegated to a mere physical attribute that is significant only for reproduction. However, for the Holy Father, sexuality is not just central to what we are as persons. It is also central to the sacramental life of the Church, especially at the point where three sacraments matrimony, Eucharist, and Orders - come together to provide the grace by which human communions of persons are drawn into the Communion of Father, Son, and Spirit in the Trinity.

The need for a male priest as a requirement for the sacramental symbol of the Eucharist brings us back to the act in which the differentiation of the sexes matters the most and is dramatically evident to the human marital act, the act of 'making love.' Here is the great sacrament in reference to Christ and the Church. Male initiative and female receptivity are especially important in the Eucharist, in which the priest reenacts the marital love of Christ the Bridegroom for his Bride, the Church. In the Eucharist, the Divine Bridegroom gives himself up for his Bride and becomes one flesh with her. Thus, matrimony, the great sacrament of which St. Paul speaks in Ephesians (5:32), while it does represent and effectively cause the presence of Christ for husband and wife, is but a faint and distant image of that divine marital act.

In this most marital of all marital acts, the initiative is entirely with the Divine Bridegroom, who "first loved us while we were yet sinners" (1Jn.4:19). That love is received then, by the free, grateful receptivity of the human persons who are the collective Bride, as we respond by our gift of ourselves to Christ, "giving up our bodies as a living sacrifice, holy and acceptable to God" (Rom.12:1). This divine marital love, in which the Son of God makes himself putty in the hands of sinners needing redemption, is the heart of the sacrifice of the Eucharist. Its counterpart is our acceptance of that gift, by which we make ourselves putty in the hands of Divine Love.

The sacramental symbolism of bride and bridegroom in the Eucharist is no small matter, for our sacraments are not just symbols. They are symbols that cause what they signify, cause it precisely by signifying it. Thus, the accuracy of the symbols is all-important. The pouring out of divine marital love in the Eucharist, then, requires that the human symbol - the visible, audible, tangible enactment of that outpouring of divine love - be accurate and clear. Otherwise, it will not effectively cause or realize that love, the love of the Divine Bridegroom for his Bride.

We have not lost the principle that all roles and actions which women are physically and psychologically capable of performing should be open to them. However, that principle has to be coupled with the sacramental nature of human sexuality. For the priest, as 'another Christ,' must be able to re-present, in what he is as a person, the initiating love of the Son of God who is also the son of Mary. He must, in other words, be a "he," not a "she." His body must have male perceptions and judgments, 
male love, male personal identity. A woman cannot, by reason of her physical and psychological makeup, stand in the place of the Bridegroom in the Eucharist, any more than a wife can exchange roles with her husband in the act of making love.

The question of women's ordination is not, then, a question of equality, of justice or rights, or of roles in a social organization. According to John Paul II (1988, $87)$, it is a question of what is and what is not ontologically possible, given the sacramental symbolism of human lovemaking and of the Eucharist. Were a woman to play the role of the priest in the Eucharist - and role-playing is all that she could - the effective power of the sacramental symbols would fail. Words would be spoken, gestures performed, but nothing real would happen.

Jesus' selection of male apostles to be his priests was not, then, a culture-bound, sexist act but a fully enlightened choice that suited his sacramental purpose. His establishment of a male priesthood was no denigration of women. They are still the religious equals of men, equally dignified, equally beloved as persons, equally capable, with the feminine primacy in loving, of the holiness to which all of us, men and women, are called. In fact, holy married women are models for priests in their search for holiness as celibate men.

\section{UNIQUENESS OF FEMALE GENDER AND THE MARIAN MODEL}

Consistent with dual gender tradition, John Paul II $(1988,91)$, cautions women not to depart from the riches of their feminine nature: "In the name of liberation from male 'domination' women must not appropriate to themselves male characteristics contrary to their own feminine 'originality.' Therefore, he supposed that each woman should live according to the special qualities proper to the fact of her femininity.

According to John Paul II $(1994,4)$, the uniqueness of a woman lies in the notion that she is made for the 'order of love': "Women can find themselves only by giving love to others." Following this train of thought, he concludes that the typical vocation for every woman is motherhood in its physical and/or spiritual dimension. Meanwhile, this concerns every woman, independently of the cultural context in which she lives and independently of her spiritual, psychological, and physical characteristics, such as age, education, health, work, and whether she is married or single.

The main focus of John Paul II's reflection on women, however, is Mary's role as mother of God, which with ineffable truth stands at the center of the mystery of God's plan of salvation. Thus, John Paul II $(2000,43)$ remarks that:

What is most important about this motherhood to which she freely consents is that it places her in union with God uniquely so on a physical level and also, in an archetypical way, representative of the whole human race on a spiritual level through grace. Since all of this happens to her precisely as a woman, she also signifies "the fullness of the perfection of what is characteristic of woman, of what is feminine. Here we find ourselves, in a sense, at the culminating point, the archetype of the personal dignity of woman. 
It follows from here that, for John Paul II, any accurate statement about woman's dignity and vocation must be rooted within this Marian scope since Mary's role in the divine plan of salvation "sheds light on women's vocation in the life of the Church and society by defining its difference in relation to man." According to him, the model Mary represents clearly shows what is specific to the feminine personality. In the encyclical letter, Redemptoris Mater, the Pope writes:

It can thus be said that women, by looking up to Mary, find in her the secret of living their femininity with dignity and of achieving their own true advancement. In the light of Mary, the Church sees in the face of women the reflection of a beauty which mirrors the loftiest sentiments of which the human heart is capable: the self-offering totality of love; the strength that is capable of bearing the greatest sorrows; limitless fidelity and tireless devotion to work; the ability to combine penetrating intuition with words of support and encouragement.

This means, therefore, that like Mary, women should emulate a lifestyle marked by an attitude of authentic service.

\section{CONCLUSION}

This study thus examined gender issues in John Paul II. The study discovers that the Pope expresses a commitment to gender equality based upon a sacramental theology wherein nature images the divine and wherein the equality of man and woman was definitively biblical. For him, man and woman are equally persons, and they are equally an image of God in whose likeness both were created. According to John Paul II, man became the image and likeness of God not only through his own humanity but also through the communion of persons which man and woman form right from the beginning

Therefore, there is a need to reaffirm the metaphysical roots of sexual difference as an anthropological refutation of attempts to negate the male-female duality of human nature. Indeed, there is a need to recognize that man has a nature that he must respect and that he cannot manipulate at will. Coexisting feminine and masculine subjectivity, however, must not imply any threat or isolation. Man and woman have been created as two persons in order to reach the full potential of what it means to be human.

The Holy Father takes human nature to be analogous in men and women, and by so doing, he shows our absolute equality with each other as persons. And yet, he gives full value to the difference, so that sex, an obvious bodily difference, is not split off from personhood but is pervasive of it. Thus, equality does not mean sameness, and difference does not mean inequality. He avoids the dilemma of both treating men and women exactly alike or else making one sex inferior to the other. Thanks to this analogy, he offers a rich and attractive view of women's dignity that takes advantage of their special traits as women and yet sets them side by side with men in a joint, complementary search for human fulfillment that is as differentiated as people are. No doubt, therefore, some women see in John Paul II a strong protagonist for true femininity 


\section{REFERENCES}

Congregation for Catholic Education. 2019. Male and female He created them: Towards a path of dialogue on the question of gender theory in education, Vatican City, February 2. http://www.vatican.va/roman_curia/congregations/ccatheduc/index.htm

Cornell, F.J. 1946. Gender inequality in household chores and work. Available at https// www. Frontiersin.org. Accessed on December 10, 2019.

International Marian Research Institute. 2000. Mary and women: John Paul II's thought on women. Dayton: University of Dayton.

John Paul II. 1988. On the dignity and vocation of women. Boston, Daughters of St. Paul Press.

John Paul II. 1995. Message of His Holiness Pope John Paul II for the XXVIII World Day of Peace: women teachers of peace, December 8.

http://www.vatican.va/content/john-paul-ii/en/messages/peace/documents/hf_jpiimrd_08121994_xxviii-world-day-for-peace.html. Accessed: November 12, 2019.

John Paul II. 1995b. Papal appeal on behalf of women, August 29. https://www.ewtn.com/catholicism/library/papal-appeal-on-behalf-of-women8724.

Koren, H.J. 1960. An introduction to the science of metaphysics, London: B. Herder Books.

Rousseau, Mary. 1990. Pope John Paul II's teaching on women. In The Catholic Women 3, Ignatius Press. pp. 22-25.

Wojtyla, K. 1981. Love and responsibility. Translated by H. T. Willets. New York: Farrar Straus \& Giroux. 